\title{
Assessment of Availability and Nutritive Values of Feed Resources and their Contribution to Livestock Nutrient Requirements in Chire District, Southern Ethiopia
}

\author{
Gashu Geremew ${ }^{1 *}$, Tegene Negesse ${ }^{2}$ and Aster Abebe ${ }^{2}$ \\ ${ }^{1}$ Chire District Bureau of Agriculture, Ethiopia \\ ${ }^{2}$ School of Animal and Range Sciences, Hawassa University, Ethiopia
}

Submission: February 02, 2017; Published: June 15, 2017

"Corresponding author: Gashu Geremew, Chire District Bureau of Agriculture, P.O. Box 5, Hawassa Ethiopia, Email: gashu2014@gmail.com

\begin{abstract}
Availability and nutritive values of feed resources and their nutrient contribution to livestock was assessed in Chire district by measuring the amount and chemical composition of feed resources and estimating balance between available and required amounts of nutrients by livestock. For the survey, agro-ecology, kebeles and households ( $\mathrm{HHs}$ ) of the district were selected using purposive multi-stage random sampling procedures. A survey was conducted on $120 \mathrm{HHs}$ and data were collected using group discussion, structured questionnaire and personal observations. Major feed samples were collected from each kebele and their chemical composition and in vitro dry matter digestibility (IVDMD) were determined. On average 13.23tons of feed dry matter (DM) per annum was produced per HH from the major feed resources. The average estimated annual livestock DM requirement for maintenance was 15.78 tons with a deficit of 2.55 tons. The available feed DM satisfies $87.22 \%$ and $79.44 \%$ of maintenance DM requirements of livestock in dega ( $>2300 \mathrm{masl})$ and woyine dega (1500-2300masl), respectively, which indicates that feed shortage was more aggravated at dega than woyine dega. Banana leaf, enset leaf and Elephant grass had reasonably high CP content than the rest of the feedstuffs. The highest percentage of IVDMD was observed in banana leaf (69.74\%) followed by elephant grass (64.26\%), and enset leaf $(61.44 \%)$ at woyine dega. Lowest IVDMD was observed in teff straw (45.08\%) and bamboo leaf (45.85\%). Ways of improving IVDMD of the available feed resources and supplementary feeds that can alleviate the feed shortage must be given priority.
\end{abstract}

Keywords: Feed availability; Chemical composition; Feed balance; Dega; Woyine dega

\section{Introduction}

Ethiopia is believed to have the largest livestock population in Africa. According to CSA (2014/15), Ethiopia owns 56.71million cattle, 29,332,382 sheep, 29,112,936 goat, 2,033115 horses, 7,428037 donkeys, 400,329 mules, 1,164106 camels, 56,886,719 poultry.

The livestock sector has been and is still contributing considerable portion to the economy of the country. The sector contributes 15 to $17 \%$ of GDP, 35 to $49 \%$ of agricultural GDP, and 37 to $87 \%$ of the household incomes [1]. Scholars Benin et al. 2003; Jabbar et al. 2007; Negassa et al, 2011; Solomon et al. [2]; ILRI [1] stated that Ethiopia has huge cattle population, diversified agro-ecological zones and farming systems but the current level of production and productivity, at either the macro or micro level is below its potential.

The availability of feed resources and the nutritional quality of the available feeds are the most important factors that determine the productivity of livestock [3]. Feed shortages and nutrient deficiencies become more acute in the dry season in both the highlands and lowlands.

For optimum livestock productivity, the available feed resource should match with the number of animals in a given area. However, there is scanty of information regarding the assessment of feed resources in the Chire district. In the Chire district, past efforts paid less attention for efficient utilization of local feed resources and mainly focused on exotic forages development. Alternative strategies for feed development that take into account the utilization of local resources that are already adapted to local environment, need to be explored before they are lost forever.

This study was conducted to assess the amount and chemical composition of livestock feed resources and estimate balance between availability and requirement in Chire district. The result of this study helped in identifying the existing feed resources, utilization practices and ways and means of improving these practices. It has helped in defining prospects for future interventions 
in developing livestock feeding systems to enhance productivity and viable integration of the crop and livestock sectors.

\section{Materials and Methods}

The study was conducted in Chire district, Sidama zone of the Southern Nations, Nationalities and Peoples' Regional State (SNNPRS). The district is located at $207 \mathrm{~km}$ away from Hawassa to the south. The land area of the district is estimated to be $39300 \mathrm{ha}$, and bordered with Nansabo district Oromia Region to the west and to the south, Bensa district to the north and Aroressa district to the east. According to MOA (2000) classification of agro-climatic zones, the district can be divided into three climatic zones, namely highland areas (Dega) >2,300 m.a.s.l, which accounts six keble's (37.5\%) of the total land, mid-altitude (Woyine Dega) 1500-2300 m.a.s.l which accounts nine kebeles (56.25\%) of the total land and lowland areas (Kolla) $<1500$ m.a.s.l, which accounts one keble' (6.25\%) of the total land areas of the District. The elevation of the Chire districts varies from 1400-3000 m.a.s.l. The mean annual rainfall of District ranges between $900-1500 \mathrm{~mm}$ while the average annual temperature of the area ranges from $15^{\circ} \mathrm{C}$ to $27^{\circ} \mathrm{C}$.

Chire district is characterized by mixed crop-livestock farming system. The livestock population of the area was estimated to be 120464 cattle, 11842 goats, 52793 sheep, 7108 donkeys, 9139 horses, 4063 mule and 59698 chickens (District Agriculture and Rural Development Office 2015). Cereals (maize, barley and teff), haricot bean, enset and coffee are the major crops produced in the area.

\section{Selection of chire district}

Two agro-ecology zones of dega and woyine dega were purposively selected based on livestock population. Kebeles were selected based on proportion of kebeles existing in each altitude zone and randomly from each altitude zones. Households were selected randomly from each kebele.

\section{Feed sample preparation}

Representative samples of available feed resources were collected during the data collection. Sample site were grouped for grazing site using $0.5 \mathrm{mx} 0.5 \mathrm{~m}$ quadrants placed randomly. Crop residues were sampled purposely from crop fields. Leaves of different plants were sampled during the dry season, a critical time when these plants serve as the alternative feed source. Thereafter, sub-samples were taken after thorough mixing for laboratory analysis. Feed samples were air-dried under shed before being transported to the laboratory, then dried at $65^{\circ} \mathrm{C}$ for $72 \mathrm{~h}$, and ground in Willey mill to pass through $1 \mathrm{~mm}$ sieve and allowed to equilibrate at room temperature for $24 \mathrm{~h}$. The samples were then put in plastic bags and sealed for further chemical analysis.

\section{Estimation of annual feed resources production and livestock feed requirements}

The quantity of feed dry matter (DM) obtained from crop residues per $\mathrm{HH}$ were estimated from grain yield to crop residue ratio using conversion factors suggested by different researchers. The multiplier used for teff, barley and wheat straw was 1.5 per unit weight of grain yield while the factors for maize and haricot bean were 2.0 and 1.2, respectively FAO 1987. The dry matter (DM) output of private grazing pasture, crop aftermath, and enset and banana leaves were estimated using multiplier 3, 0.5 and 8 tons DM/ha/year, respectively (FAO 1987, MOA 2001). The daily DM requirement for maintenance of one TLU was estimated to be $2.5 \%$ of the body weight (ILCA, 1991) which is $250 \times 2.5 \%=6.25 \mathrm{~kg}$ DM daily or $2.28 \mathrm{t}$ DM per year.

\section{Chemical Analysis}

Dry matter (DM) and total nitrogen (N) contents of feed samples were determined following standard method of [4]. Crude protein (CP) was calculated as Nx6.25. Ash was determined by complete burning of the feed samples in a muffle furnace at $500{ }^{\circ} \mathrm{C}$ overnight, according to the procedure of AOAC [4]. Neutral detergent fiber (NDF) and acid detergent fiber (ADF) were analyzed using the detergent extraction method [5].

\section{In vitro dry matter digestibility}

In vitro dry matter digestibility was determined by the method of Tilley \& Terry [6] as modified by Van Soest \& Robertson [5]. Rumen fluid was collected from sheep by means of esophageal tube.

\section{Statistical analysis}

The statistical analysis was carried out using a statistical package for social science (SPSS version 16). Data analysis involved the use of appropriate descriptive statics and frequencies. Means were separated using Tukey test and were considered significant at $\mathrm{P}<0.05$.

\section{Result and Discussion}

\section{Land holding and land use pattern}

Table 1: Average land use patterns and holding size (ha, Mean \pm SE) per household in dega and $(\mathrm{N}=60)$ and woyine dega zone $(\mathrm{N}=60)$.

\begin{tabular}{|c|c|c|c|}
\hline Land Holding & $\begin{array}{c}\text { Dega Zone } \\
\mathbf{( N = 6 0 )}\end{array}$ & $\begin{array}{c}\text { Woyine Dega } \\
\text { Zone }(\mathbf{N = 6 0})\end{array}$ & $\begin{array}{c}\text { Overall } \\
\mathbf{( N = 1 2 0 )}\end{array}$ \\
\hline Cultivated land & & & \\
\hline Own & $2.4 \pm 0.12$ & $2.38 \pm 0.12$ & $2.39 \pm 0.16$ \\
\hline Rented & $0.19 \pm 0.05$ & $0.75 \pm 0.03$ & $0.13 \pm 0.03$ \\
\hline Total & $2.6 \pm 0.10$ & $2.45 \pm 0.12$ & $2.52 \pm 0.15$ \\
\hline Grazing land & & & \\
\hline Own & $0.69 \pm 0.06 \mathrm{a}$ & $0.31 \pm 0.07 \mathrm{~b}$ & $0.504 \pm 0.04$ \\
\hline Rented & $0.8 \pm 0.03 \mathrm{a}$ & $0.05 \pm 0.02 \mathrm{~b}$ & $0.068 \pm 0.19$ \\
\hline Total & $0.78 \pm 0.06 \mathrm{a}$ & $0.35 \pm 0.07 \mathrm{~b}$ & $0.57 \pm 0.53$ \\
\hline Total own & $3.09 \pm 0.28$ & $2.99 \pm 0.26$ & $2.99 \pm 0.27$ \\
\hline Total rented & $0.99 \pm 0.08$ & $0.13 \pm 0.04$ & $0.56 \pm 0.60$ \\
\hline Overall total & $4.08 \pm 0.36$ & $3.12 \pm 0.30$ & $3.62 \pm 0.15$ \\
\hline
\end{tabular}

Means with different superscript letters within a row between zones are significantly different $(P<0.05) \mathrm{N}$ : Number of Respondents; SE: Standard Error

Landholding and land use pattern of respondents in the study district is summarized in Table 1 . The overall average household land holding size of the Chire district was 2.99 ha and about 0.56 ha was total rented land Chire district. Out of total land owned per 
household in dega zone was 2.6ha and woyine dega zone was 2.45 ha of land was allocated for crop cultivation and 0.78 ha in dega and 0.35 ha in woyine dega zone was allocated for private grazing.

\section{$(\mathrm{P}<0.05) \mathrm{N}=$ number of respondents, $\mathrm{SE}=$ standard error}

\section{Livestock holding and composition}

Tropical livestock unit of the district was 5.6 per household with dega having $(6.3)$ more $(p<0.05)$ than that $(4.9)$ of woyine dega. Cattle were most important livestock species in both agroecologies (Table 2). Mean cattle holding size was much lower than that reported (11TLU) for Adami Tullu Jiddo Kombolcha District (Duressa, 2007), (8.7TLU) for Sinana, (11.5TLU) for Dinsha (Solomon, 2004) and (11TLU) for Badewacho and Soddo Zuria districts (Netsanet, 2006). The smaller TLU per HH in the Chire district could be attributed to shrinkage of grazing land.

Table 2: Livestock holding and composition and feed sources per household in dega and woyine dega kebeles of Chire district (TLU).

\begin{tabular}{|l|c|c|c|}
\hline $\begin{array}{l}\text { Livestock } \\
\text { Species }\end{array}$ & Dega (N=60) & $\begin{array}{c}\text { Woyine Dega } \\
\text { (N=60) }\end{array}$ & Overall Mean \\
\hline Cattle & \multicolumn{3}{|c|}{ Tropical livestock unit } \\
\hline Bull & 1.03 & 0.68 & 0.86 \\
\hline Ox & 0.24 & 0.13 & 0.19 \\
\hline Heifer & 1.34 & 1.13 & 1.24 \\
\hline Cow & 2.58 & 2.34 & 2.46 \\
\hline Sheep & 0.35 & 0.08 & 0.21 \\
\hline Goat & - & 0.05 & 0.03 \\
\hline Donkey & - & 0.06 & 0.03 \\
\hline Horse & 0.6 & 0.02 & 0.31 \\
\hline Mule & 0.02 & 0.09 & 0.06 \\
\hline Chicken & 0.13 & 0.3 & 0.22 \\
\hline Feed resources & & $\%$ & \\
\hline Natural pasture & 50 & 35 & \\
\hline Crop residues & 21.6 & 0.1 & \\
\hline Crop root & 13.3 & 43.3 & \\
\hline $\begin{array}{l}\text { Crop after } \\
\text { math }\end{array}$ & 13.3 & 6.7 & \\
\hline Hay & - & 1.7 & \\
\hline Supplements & 1.6 & 3.3 & \\
\hline
\end{tabular}

TLU: Tropical Livestock Unit; N: Number of Respondents

\section{Feed resources availability}

Feed problem is one of major factors that hinders the production and productivities of livestock in the Chire district. Natural pasture and root crops (enset and banana leaf) were ranked $1^{\text {st }}$ and are primary source of feed to livestock in both agro-ecological zones of the Chire district (Table 2). In general crop residues and natural pasture are the major feed resources of the dega kebeles which agree with Tolera et al. [7], Alemayehu (2004) who reported natural pasture and crop residues to be the major feed resources for highlands of Ethiopia

\section{Improved for age development practice and their utilization}

This study indicated that there was less experience in growing improved forage. Majority of respondents mentioned that they do not cultivate improved forage (Table 3 ) at dega and woyine dega respectively. Admasu [8] has also reported that forage development is a key to skip feed shortages if practiced but it is at an infant stage in terms of usage. Proportion of farmers producing improved forage was only minimal at dega but slightly better at woyine dega. Moreover, reasonable population of respondents conserves feed to overcome seasonal feed shortage problem in dega than woyine dega.

Table 3: Levels of improved forage development and utilization practices.

\begin{tabular}{|l|c|c|c|c|}
\hline \multirow{2}{*}{ Respondent Experience } & \multicolumn{2}{|c|}{$\begin{array}{c}\text { Dega Zone } \\
\text { (N=60) }\end{array}$} & \multicolumn{2}{c|}{$\begin{array}{c}\text { Woyine Dega } \\
\text { Zone (N=60) }\end{array}$} \\
\cline { 2 - 5 } & No & Yes & No & Yes \\
\hline Cultivate improved forage (\%) & 93.3 & 6.7 & 81.7 & 18.3 \\
\hline Conserve feed (\%) & 58.3 & 41.7 & 71.7 & 28.3 \\
\hline Treat crop residues (\%) & 75 & 25 & 65 & 35 \\
\hline $\begin{array}{l}\text { Reasons for not producing improved } \\
\text { forage }\end{array}$ & & N (\%) & & Rank \\
\hline Lack of awareness & & $64(53.3)$ & & 1 \\
\hline Lack of seed & & $28(23.4)$ & & 2 \\
\hline Shortage land & & $16(13)$ & & 3 \\
\hline Availability of other feed sources & & $12(10.3)$ & & 4 \\
\hline
\end{tabular}

\section{Estimation of available feed resources}

Table 4: Estimated annual feed dry matter obtained per household farm from different feed resources

\begin{tabular}{|l|c|c|c|c|}
\hline \multirow{2}{*}{ Sources of Feed } & \multicolumn{4}{|c|}{ Feed Production (T DM/HH) } \\
\cline { 2 - 5 } & $\begin{array}{c}\text { Dega } \\
\text { (N=60) }\end{array}$ & $\begin{array}{c}\text { Woyine dega } \\
\text { (N=60) }\end{array}$ & $\begin{array}{c}\text { Average } \\
\text { (DM) }\end{array}$ & \% \\
\hline Maize stover & - & 2.5 & 1.25 & 29.48 \\
\hline Teff straw & $0.02^{\mathrm{b}}$ & $0.75^{\mathrm{a}}$ & 0.39 & 9.19 \\
\hline Wheat straw & 1.5 & - & 0.75 & 17.68 \\
\hline Barely straw & 2.55 & - & 1.27 & 29.95 \\
\hline Haricot bean straw & - & 0.35 & 0.18 & 4.24 \\
\hline Bean & 0.55 & 0.25 & 0.25 & 9.19 \\
\hline Total crop residues & $4.62^{\mathrm{a}}$ & $3.85^{\mathrm{b}}$ & 4.24 & 100 \\
\hline Utilizable crop residues & $4.16^{\mathrm{a}}$ & $3.47^{\mathrm{b}}$ & 3.84 & 29.02 \\
\hline Aftermath & $2.00^{\mathrm{a}}$ & $0.70^{\mathrm{b}}$ & 1.35 & 10.2 \\
\hline Private grazing & $4.50^{\mathrm{a}}$ & $1.05^{\mathrm{b}}$ & 2.76 & 20.86 \\
\hline Fallow land & 0.5 & 0.35 & 0.43 & 3.25 \\
\hline Forest/ woody land & 0.25 & 0.4 & 0.31 & 2.34 \\
\hline Enset and banana leaf & $4.08^{\mathrm{b}}$ & $5^{\mathrm{a}}$ & 4.54 & 34.31 \\
\hline Total DM available & $15.49^{\mathrm{a}}$ & $10.97^{\mathrm{b}}$ & 13.23 & 100 \\
\hline
\end{tabular}

The dry matter obtained from different feed resources is presented in Table 4 . The average utilizable dry matter output obtained per household from private grazing land was higher for dega than woyine dega. The overall average utilizable dry matter output produced annually from crop residues per household was lower than that (6.7 tons DM) reported by Solomon et al. [2] in 
the Bale high land. The differences in varieties and types of crops; quality and quantity of fertilizers used; plant protection measures which may also lead to differences in vegetative growth and yield [9]. More than half of the residue DM was contributed by maize stover and barley straw.

\section{Estimation of feed supply and feed requirement}

According to Table 5 the average annual utilizable feed dry matter in dega zone required for maintenance was higher than the actual DM production which could not completely support it. Similar negative feed balances were also reported by Admasu [8] and Wondatir [10] in Wolayita Sodo, Alaba District and central Rift Valley of Ethiopia.

Table 5: Estimated annual utilizable feed DM supply, DM requirement and feed balance per household.

\begin{tabular}{|l|c|c|c|}
\hline \multirow{2}{*}{ Parameters } & \multicolumn{3}{|c|}{ Agro-Ecology } \\
\cline { 2 - 4 } & Dega & Woyine dega & Average \\
\hline Annual feed DM supply $(\mathrm{t})$ & 15.49 & 10.97 & 13.23 \\
\hline $\begin{array}{l}\text { Requirement for maintenance } \\
\text { (t DM/year) }\end{array}$ & 17.76 & 13.81 & 15.78 \\
\hline Balance of requirement (t) & -2.27 & -2.84 & -2.55 \\
\hline$(\%)$ & -12.88 & -20.56 & -16.66 \\
\hline
\end{tabular}

\section{DM: Dry Matter; t: tone}

\section{Seasonality of feed resources availability}

The type, quality and quantity of available feed resource are influenced by season. Commonly available feed resources at different times of the year are presented in (Table 6). Natural pastures, thinning and green maize stover, weeds and different browse species are used during most part of the year.

Table 6: Season of the year when different feeds are available in the Chire district.

\begin{tabular}{|l|l|l|l|}
\hline Feed Type Resources & Sept.-Nov. & Dec.-Apr. & May-Aug. \\
\hline Natural pasture & & & \\
\hline Dry maize Stover & & & \\
\hline Green maize stover & & & \\
\hline Teff straw & & & \\
\hline Barely straw & & & \\
\hline Crop after math & & & \\
\hline Cut-and-carry grass & & \\
\hline Enset leaves and other parts & & & \\
\hline Browses and weeds & & & \\
\hline
\end{tabular}

Note: The shaded area shows the months during which the given feed resources are available for animal feeding.

\section{Chemical composition and nutritive value of feeds}

Chemical composition and nutritive values of major feed resources are shown in Table 7. The high fiber and low crud protein contents of the different feed resources could be related to varietal differences, location or climate, fertility of the land, stage of maturity at harvest, morphological fraction fed, method of harvesting and transporting, length and condition of storage (Archimade et al 2002). The relatively high CP content of enset leaf is in line with the values (17\%) reported by Adugna [11] at southern Ethiopia, which makes it a favorable feed resource in ruminant feeding. High CP combined with low NDF and ADF contents are indicators of good forage quality (Aregheore, 2007). The highest digestibility coefficient was observed in banana leaf followed by elephant grass and enset leaf at woyine dega. Lower IVDMD values were observed in teff straw and in bamboo leaf which is likely associated with their higher lignin content compared to the other feed resources. IVDMD of enset leaf at both agro-ecologies was almost similar and higher than earlier report (69.2\%) of Adugna [12].

The nutritive value of crop residues is variable depending upon the species and variety of the crops, time of harvest, handling and storage conditions and other factors [13-28].

Table 7: Chemical composition (\%) and in vitro dry matter degradability of major feed resources in Chire district.

\begin{tabular}{|l|l|l|l|l|l|l|l|}
\hline \multirow{2}{*}{ Feed type } & \multicolumn{2}{|c|}{ Lab DM } & \multicolumn{5}{c|}{ \% of DM } \\
\cline { 2 - 8 } & $\begin{array}{l}\text { Agro- } \\
\text { Ecology }\end{array}$ & (\%) & Ash & CP & NDF & ADF & IVDMD \\
\hline $\begin{array}{l}\text { Natural } \\
\text { pasture }\end{array}$ & Dega & 90 & 4.5 & 7.5 & 69.49 & 33.12 & 56.52 \\
\hline $\begin{array}{l}\text { Natural } \\
\text { pasture }\end{array}$ & $\begin{array}{l}\text { Woyine } \\
\text { dega }\end{array}$ & 91.5 & 6 & 6.25 & 67.51 & 31.18 & 59.42 \\
\hline $\begin{array}{l}\text { Elephant } \\
\text { grass }\end{array}$ & $\begin{array}{l}\text { Woyine } \\
\text { dega }\end{array}$ & 89.5 & 7.5 & 16.09 & 67.11 & 34.02 & 64.26 \\
\hline Enset leaf & Dega & 94 & 9.5 & 12.21 & 56.36 & 25 & 60.79 \\
\hline Enset leaf & $\begin{array}{l}\text { Woyine } \\
\text { dega }\end{array}$ & 91 & 8 & 14.93 & 57.23 & 26.59 & 61.44 \\
\hline Banana leaf & $\begin{array}{l}\text { Woyine } \\
\text { dega }\end{array}$ & 88 & 7.5 & 13.62 & 55.44 & 25.19 & 69.74 \\
\hline $\begin{array}{l}\text { Sugar cane } \\
\text { leaf }\end{array}$ & $\begin{array}{l}\text { Woyine } \\
\text { dega }\end{array}$ & 85 & 8.5 & 6.37 & 74.01 & 39.39 & 50.45 \\
\hline Bamboo leaf & Dega & 92 & 7 & 10.96 & 69.52 & 31.58 & 45.85 \\
\hline $\begin{array}{l}\text { Maize } \\
\text { strover }\end{array}$ & $\begin{array}{l}\text { Woyine } \\
\text { dega }\end{array}$ & 93 & 8 & 5.67 & 72.55 & 26.62 & 59.42 \\
\hline Teff straw & $\begin{array}{l}\text { Woyine } \\
\text { dega }\end{array}$ & 91 & 3 & 5.56 & 77.5 & 39.39 & 45.08 \\
\hline Barley straw & Dega & 92.4 & 4.2 & 4.1 & 76 & 42 & 52.1 \\
\hline
\end{tabular}

Abbreviations: DM: Dry Matter; Cp: Crude Protein; NDF: Neutral Detergent Acid, ADF: Acid Detergent Fiber; ADL: Acid Detergent Lignin, IVOMD: In vitro Organic Matter Digestibility

\section{Conclusion and Recommendation}

From this study it can be concluded that the major feed resources available in Chire district were natural pasture, different parts of enset and banana and crop residues. Available feed resources do not meet nutrient requirements to get optimum benefits from the livestock sector. Introducing improved forages and conservation of exiting forage/natural pasture in the form of hay at the end of rainy season might be part of the solution.

\section{Acknowledgement}

The authors acknowledge the Chire district Bureau of Agriculture for giving the chance to pursue this study. 


\section{References}

1. ILRI (International Livestock Research Institute) (2010) Diagnostic study of live cattle and beef production and marketing. Addis Ababa, Ethiopia, p. 14.

2. Solomon B, Solomon M, Alemu Y (2008) Influence of rainfall pattern on grass/legume composition and nutritive value of natural pasture in Bale Highlands of Ethiopia. Livestock Research for Rural Development.

3. Ahmed H, Abule E, Mohammed K, Treydte AC (2010) Livestock feed resources utilization and management as influenced by altitude in the Central Highlands of Ethiopia. Livestock research for rural development.

4. AOAC (2000) Official methods of analysis of the association of official analytical chemists. (15 th edn), Association of Official Analytical Chemists (AOAC), Washington, USA.

5. Van Soest PJ, Robertson JB, Lewis BA (1991) Methods for Dietary fiber, Neutral Detergent Fiber and Non-Starch Polysaccharides in relation to Animal Nutrition. J Dairy Sci 74(10): 3583-3597.

6. Tilly JMA, Terry RA (1963) A two-stage technique for the invitro digestion of forage crops. Journal of British, Grassland Society 18(2): 104-111.

7. Tolera A, Said AN (1994) Assessment of Feed Resources in Welayta Sodo. Eth J Agric Sci 14(1/2): 69-87.

8. Admasu Y (2008) Assessment of livestock feed resources utilization in Alaba woreda, southern Ethiopia. MSc Thesis, Haramaya University, Dire Dewa, Ethiopia, p. 58.

9. Reddy RMG, Rao MM, Murthy SKK (1998) A multiple regression model for predicting groundnut yields in arid zones using weather parameters. Trop Agric 75(4): 321-331.

10. Wondatir Z (2010) Livestock production system in relation to feed availability in the highlands and central rift valley of Ethiopia. MSc. Thesis. Haramaya Universit, Dire Dewa, Ethiopia, p. 31.

11. Adunga T, Yami A, Alemu D (2012) Livestock feed resources in Ethiopia: Challenges, Opportunities and the need for transformation. Ethiopia Animal Feed Industry Association, Addis Ababa, Ethiopia.

12. Tolera A (2007) Feed Resources for Producing Export Quality Meat \& Livestock in Ethiopia. Ethiopia, pp: 75-79.

13. Tolera A (2008) Feed resources and feeding management: A manual for feedlot operator and development workers, September 2008. Addis Ababa, Ethiopia, pp. 22-31.

14. Tolera A (2009) Livestock feed supply situation in Ethiopia. Proceeding of the $16^{\text {th }}$ Annual Conference of the Ethiopian Society of Animal Production, 2008. Addis Ababa, Ethiopia, pp. 21-38.

15. Mengistu A (2007) Pasture and Forage Resource profiles of Ethiopia. Ethiopia FAO, Addis Ababa, Ethiopia, p. 19.
16. Yami (2009) Nutrition and feeding of Sheep and Goat. In: Ethiopian sheep and Goat Production Improvement Program,

Ethiopia, pp. 106-159.

17. CSA (Central Statistics Agency) (2014) Agriculture sampler survey Volume II Report on live stock and live stock characteristics, Ethiopia.

18. Dawit A, Ajebu N, Sandip B (2013) Assessment of feed resource availability and livestock Production constraints in selected Kebeles of Adami Tullu Jiddo Kombolcha district, Ethiopia. African Journal of Agricultural Research 8(29): 4067-4073.

19. Denbeshu D (2010) Utilization and nutritive value of mountain bamboo (Yushania alpina) leaves from sidama highlands, southern Ethiopia A thesis submitted to the Department of animal and range sciences, Hawassa College of agriculture, school of graduate studies Hawassa University, Hawassa, Ethiopia.

20. Getu D (2012) Effect of supplementation of two varieties of sweet potato vine (Ipomoa batata lam) on weight gain and carcass characteristic of grazing Arsi-Bale sheep I Shebedino Woreda, Sidama Zone, southern Ethiopia. M.sc Thesis, Hawassa University, Hawassa, Ethiopia.

21. Girma D (2010) Effects of urea treatment and concentrate mix supplementation on feed intake, digestibility, weight gain and carcass characteristics of Horro sheep fed maize husk. MSc Thesis, Haramaya University, Ethiopia.

22. ILRI (International Livestock Research Institute) (2011) Sheep and goat production and marketing systems in Ethiopia: Characteristics and strategies for improvement strategies. ILRI Editorial and Publishing Services, Addis Ababa, Ethiopia.

23. Mc Donald P, Edwards AR, Greenhalgh DFJ, Morgan AC (2002) Animal nutrition. (6 ${ }^{\text {th }}$ edn), Longman Group, Harlow, UK, p. 607.

24. Mo A (Ministry of Agriculture) (2000) Agroecological Zonations of Ethiopia. Addis Ababa, Ethiopia.

25. Mulu S (2009) Feed resource availability, cattle fattening practices and marketing system in Bure Woreda, Amhara Region, Ethiopia. MSc Thesis, Mekele University, Ethiopia, p. 51.

26. Nurfeta A (2008) Evaluation of the nutritive value of enset (Enset ventricosum) as livestock feed in southern Ethiopia. PhD Thesis, Norwegian University of Life Sciences, Norway.

27. Nurfeta A (2010) Feed intake, digestibility, nitrogen utilization and body weight change of sheep consuming wheat straw supplemented with local agricultural and agro-industrial by-products. Tropical Animal Health and Production 42(5): 815-882.

28. Bogale S (2004) Assessment of livestock production system and feed resource base in Sinana Dinsho Distirct of Balehighlands, South East Oromiya. MSc Thesis, Alemaya University, Ethiopia.

Your next submission with Juniper Publishers
will reach you the below assets
- Quality Editorial service
- Swift Peer Review
- Reprints availability
- E-prints Service
- Manuscript Podcast for convenient understanding
- Global attainment for your research
- Manuscript accessibility in different formats
( Pdf, E-pub, Full Text, Audio)
- Unceasing customer service
Track the below URL for one-step submission
https://juniperpublishers.com/online-submission.php

